\title{
OXYGEN CONTROL FOR EPITAXIAL GROWTH OF CUPRATES IN ULTRAHIGH VACUUM SYSTEM
}

\section{超高真空系における酸化物高温超伝導体の酸素制衙}

\author{
Hideomi Koinuma \\ Research Laboratory of Engineering Materials \\ Tokyo Institute of Technology \\ 4259 Nagatsuta, Midori-ku, Yokohama 227 \\ Tel. 81-45-922-1111 Fax. 81-45-921-1015
}

(Received 17, December 1991 Accepted 18, December 1991)

\begin{abstract}
The oxidation ability of various oxidants for $\mathrm{Bi}_{2} \mathrm{Sr}_{2} \mathrm{CaCuO}_{\mathbf{x}}$ and related cuprates were evaluated both by experiments and by a thermodynamical calculation. When $\mathrm{B}_{i 2} \mathrm{Sr}_{2} \mathrm{CaCu}_{2} \mathrm{O}_{\mathrm{x}}$ sputtered films were treated at $400{ }^{\circ} \mathrm{C}$ with such oxidants as photo-activated $\mathrm{O}_{2}, \mathrm{NO}_{2}, \mathrm{O}_{3}$, and $\mathrm{N}_{2} \mathrm{O}$, significant Tc change was observed. This TC change was found in parallel with the variation of clattice parameter and verified to originate from oxygen nonstoichiometry in the films by the Hall coefficient measurement. The highly oxidative property of $\mathrm{NO}_{2}$, ozone, and atomic oxygen derived from this experiment was supported by the thermodynamical calculation for the oxidation of $\mathrm{Cu}_{2} \mathrm{O}$ to CuO. The results were further utilized to grow alkaline earth cuprate films by pulsed laser deposition in ultrahigh vacuum (laser MBE). In situ RHEED and XPS analyses clearly indicated that alkaline earth cuprates could be grown epitaxially and laterally under such conditions as $700{ }^{\circ} \mathrm{C}$ and 1 x $10^{-7} \mathrm{NO}_{2}$ pressure.
\end{abstract}

Keywords: oxygen control, superconducting film, cuprate, oxidation in UHV, laser MBE

\section{INTRODUCTION}

Oxygen plays a vitally important role in high Tc superconductors (HTSC), since it is a constituent of crystal lattice and is a carrier source as well. For electronic device application of HTSC, primarily required is the fabrication of HTSC thin films at low ( $\left.\leq 500{ }^{\circ} \mathrm{C}\right)$ temperature. Optimization of oxygen content, $i$. e. hole concentration at low temperature is one of the key technologies and several methods were reported to be effective for this purpose. Oxygen plasma and ozone were used by Moriwaki et al., 1 and Berkeley et al., 2 respectively, for the oxidation of $\mathrm{YBa}_{2} \mathrm{Cu}_{3} \mathrm{O}_{7-\delta}$, while $\mathrm{N}_{2} \mathrm{O}, \mathrm{NO}_{2}$, and UV light activated $\mathrm{O}_{2}$ were by M. Kanai et al., 3 Watanabe et al., 4 and us, 5 respectively, for the oxidation of $\mathrm{Bi}-\mathrm{Sr}-\mathrm{Ca}-\mathrm{Cu}-\mathrm{O}$ system. These experimental studies were done independently and systematic comparison among the methods has scarcely been reported. In view of the commonly observed layered perovskite structure in HTSC, we can expect to construct not only the same structure but also artificially designed new structures if a technology for atomically regulated epitaxial growth of ceramics could be established. An ultrahigh vacuum (UHV) process such as molecular beam epitaxy (MBE) should be desirable for this purpose, but it can be applied by solving the 
problem of oxygen control in growing film surface in UHV. This paper reports on fundamental problems of oxygen control at low temperature as well as in UHV condition and presents some experimental results of ceramic layer epitaxy by laser MBE which we are developing for establishing a technology of fabricating artificial ceramic lattices.

\section{OXYGEN CONTROL IN $\mathrm{Bi}_{2} \mathrm{Sr}_{2} \mathrm{CaCu}_{2} \mathrm{O}_{\mathrm{X}}$ FILMS BY ACTIVATED OXYGENS \\ The oxygen control in a}

superconducting thin films and the verification of its effect on Tc were investigated by exposing sputterdeposited $\mathrm{Bi}_{2} \mathrm{Sr}_{2} \mathrm{CaCu}_{2} \mathrm{O}_{x}$ ( $\mathrm{Tc}$, onset $=$ $80 \mathrm{~K})$ films to several active oxygen compounds at $400^{\circ} \mathrm{C}$. Relationships were evaluated among TC, c-lattice parameter, and Hall coefficient of the oxygen treated films and discussed in relation to the oxygen nonstoichiometry.

\section{2-1. EXPERIMENTAL}

An ac sputtering apparatus shown in Fig.1 was used for both film synthesis and oxygen treatment. ${ }^{6} \mathrm{~A}$ pair of disc $\mathrm{Bi}_{2} \mathrm{Sr}_{2} \mathrm{Ca}_{2} \mathrm{Cu}_{3} \mathrm{O}_{\mathrm{Y}}$ targets mounted on the glass-covered copper rods were sputtered by the

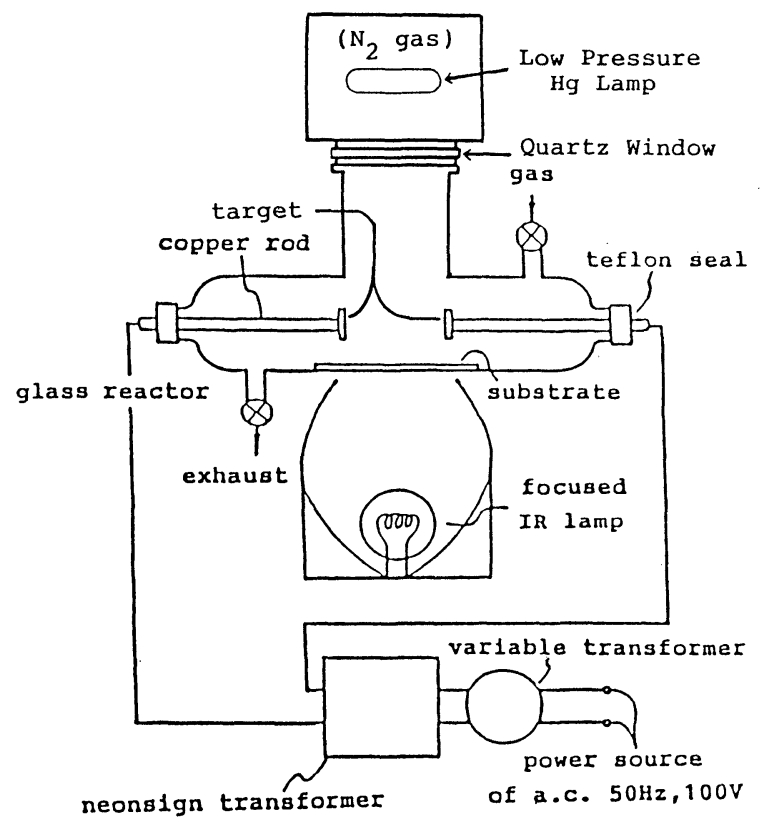

Fig.1. The schematic representation of the ac $50 \mathrm{~Hz}$ sputtering apparatus. application of $50 \mathrm{~Hz}$ ac high voltage to deposit thin films of about $0.8 \mu \mathrm{m}$ in $2 \mathrm{~h}$ on yttria stabilized zirconia (YSZ) substrates. As-deposited films were annealed at $850{ }^{\circ} \mathrm{C}$ for $30 \mathrm{~min}$ to show XRD patterns almost identical to that of c-axis oriented $\mathrm{Bi}_{2} \mathrm{Sr}_{2} \mathrm{Ca}_{1} \mathrm{Cu}_{2} \mathrm{O}_{\mathrm{x}}$ phase. The film specimens thus prepared have Tc onset of about $80 \mathrm{~K}$. Oxygen, ozone and nitrous oxide with or without UV light irradiation and oxygen plasma were employed for oxygen treatments. The oxygen plasma was generated at 0.4 Torr of $\mathrm{O}_{2}$ by the application of ac $3.6 \mathrm{kV}$ between a pair of stainless-steel electrodes, which were replaced from the targets after the film deposition, facing each other $6 \mathrm{~cm}$ apart. Ozone was generated by using a micro ozonizer (Erstat Laboratory AOC-05) and introduced in the apparatus. Every activated oxygen treatment of the film was carried out at $400{ }^{\circ} \mathrm{C}$ for 30 min and at decreasing temperatures to about $50{ }^{\circ} \mathrm{C}$ for additional $30 \mathrm{~min}$.

The resistivity of the films was measured by the dc four probe method. The crystal structure of the films was analyzed using an $\mathrm{X}$-ray diffractometer (XRD, Mac Science MXP3, $\operatorname{CuK} \alpha$ ). Hall coefficient of the films was measured by standard van der Pauw technique at room temperature under a magnetic field of $1 \mathrm{~T}$.

\section{2-2.RESULTS and DISCUSSION}

Figure 2 shows the temperature dependence of resistivity for some of the specimens after activated oxygen treatments. The application of ozone (C) or oxygen plasma (D) decreased the Tc onset of the film from $80 \mathrm{~K}$ to about $60 \mathrm{~K}$. Activated oxygen treatments did not produce a new XRD peak but gave small shifts towards higher diffraction angles in the $c$ lattice constants. The Tc values of these films returned to about $80 \mathrm{~K}$ when the films were subjected to further heat treatment in atmospheric oxygen without the light irradiation. All these results were essentially 
the same as in the case of UV light irradiation in the presence of atmospheric oxygen (B) ${ }^{5}$ and prompted us to consider that these activated oxygen treatments should increase the oxygen content in the films and induce the decrease of $c$ lattice constant and critical temperature.

on the other hand, the treatment of film with 400 Torr $\mathrm{N}_{2} \mathrm{O}$ under UV light irradiation increased the TC onset from $80 \mathrm{~K}$ to $100 \mathrm{~K}(\mathrm{Fig} .2$, (E)). The XRD ( $00 \mathrm{C})$ peaks shifted towards lower diffraction angles. This film gave the Tc onset of about $60 \mathrm{~K}$ and higher diffraction angles after the treatment of atmospheric oxygen with the UV light irradiation. These TC changes were reversible, which means the Tc changes were induced only by the change of oxygen content in the film. Oxygen treatments activated by UV light and plasma worked to incorporate the oxygen into the films, whereas $\mathrm{N}_{2} \mathrm{O}$ treatment with UV

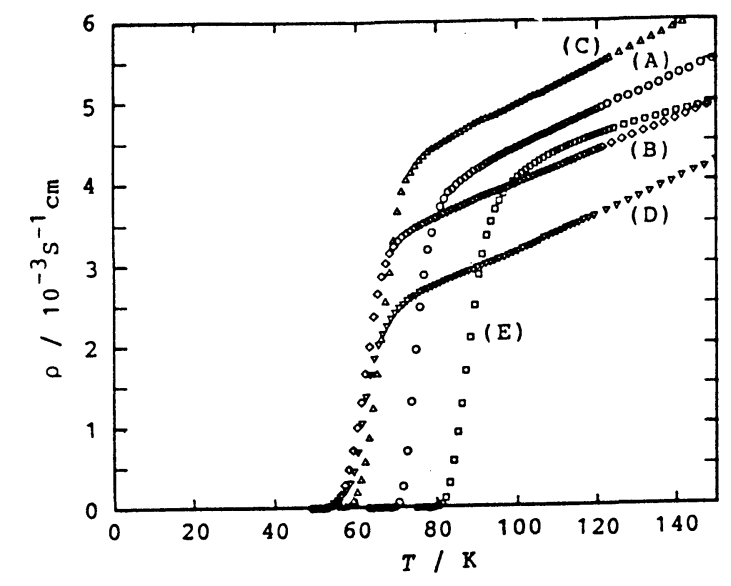

Fig.2. Temperature dependence of resistivity for $\mathrm{Bi}_{2} \mathrm{Sr}_{2} \mathrm{Ca}_{1} \mathrm{Cu}_{2} \mathrm{O}_{\mathrm{x}}$ films treated by some activated oxygens.

(A) $\mathrm{O}_{2} 1 \mathrm{~atm}$, (B) $\mathrm{O}_{2} 1 \mathrm{~atm} / \mathrm{UV}$, (C) $\mathrm{O}_{3} 1$ atm, (D) Oxygen plasma, (E) $\mathrm{N}_{2} \mathrm{O} 400$ Torr/UV. light irradiation apparently worked to reduce the oxygen content in the film. This effect of $\mathrm{N}_{2} \mathrm{O} / \mathrm{UV}$ treatment was rather contrary to our intuition, since atomic oxygen should also be formed from $\mathrm{N}_{2} \mathrm{O}$ by the UV light irradiation. The adsorption of $\mathrm{N}_{2} \mathrm{O}$ and oxygen extraction from the oxide film surface to liberate $\mathrm{N}_{2}$ and $\mathrm{O}_{2}$ can be the origin of reducing effect of $\mathrm{N}_{2} \mathrm{O}$.

The TC onset of the oxygen treated films could be linearly correlated with the c-lattice length up to $3.072 \mathrm{~nm}$. However, films with c-parameter longer than $3.075 \mathrm{~nm}$ became semiconductive. Kinetics should also be taken into account for the oxygen control in the film, since the activated oxygen treatment at room temperature gave almost no change in TC.

Hall coefficients $\left(R_{H}\right)$ were measured for the specimens treated under three typical activated oxygen treatments listed in Tab. 1. The signs of the $R_{H}$ were positive, suggesting that the charge carrier was hole. Table 1 also shows the relationship between the hole concentration $\left(1 / \mathrm{eR}_{\mathrm{H}}\right)$ and Tc. The hole concentration is consistent with the oxidation behavior described above; the overdoping of hole carriers in $\mathrm{Bi}_{2} \mathrm{Sr}_{2} \mathrm{CaCu}_{2} \mathrm{O}_{\mathrm{x}}$ film by highly active oxidants induced the TC decrease.

\section{THERMODYNAMICAL CONSIDERATION ON OXIDATION ABILITY OF OXIDANTS}

From the above study, the high oxidation ability of $\mathrm{NO}_{2}$, photochemically activated $\mathrm{O}_{2}$, and ozone were qualitatively confirmed. Then we tried to evaluate the

Table 1. Activated oxygen treatment conditions, $\mathrm{T}_{\mathrm{C}}$ onset, Hall coefficients and carrier concentrations.

\begin{tabular}{ccccc} 
specimen & $\begin{array}{l}\text { activated oxygen } \\
\text { treatment condition }\end{array}$ & $\begin{array}{c}\mathrm{T}_{\mathrm{C}} \text { onset } \\
(\mathrm{K})\end{array}$ & $\left(10^{-3} \mathrm{Rm}_{\mathrm{H}} / \mathrm{C}\right)$ & $\begin{array}{c}\mathrm{N}_{\mathrm{H}}\left(=1 / \mathrm{eR}_{\mathrm{H}}\right) \\
\left(10^{21} \mathrm{~cm}^{-3}\right)\end{array}$ \\
\hline $\mathrm{F}$ & $\mathrm{O}_{2} 1 \mathrm{~atm} / \mathrm{UV}$ & 69 & 4.0 & 1.6 \\
$\mathrm{G}$ & $\mathrm{O}_{2} 1$ atm & 91 & 6.0 & 1.0 \\
$\mathrm{H}$ & $\mathrm{N}_{2} \mathrm{O} 4 \mathrm{Torr} / \mathrm{UV}$ & 103 & 7.2 & 0.87 \\
\hline
\end{tabular}


oxidation ability of various oxidants quantitatively by thermodynamical calculation so that we could estimate the possibility of as-grown oxide film growth even in UHV condition. 7 In the calculation, the coexistence of $\mathrm{Cu}_{2} \mathrm{O} / \mathrm{CuO}$ in the following seven equilibria was assumed:

$$
\begin{aligned}
& 2 \mathrm{Cu}_{2} \mathrm{O}(\mathrm{s})+\mathrm{O}_{2}(\mathrm{~g}) \rightarrow 4 \mathrm{CuO}(\mathrm{s}) \\
& 3 \mathrm{Cu}_{2} \mathrm{O}(\mathrm{s})+\mathrm{O}_{3}(\mathrm{~g}) \rightarrow 6 \mathrm{CuO}(\mathrm{s}) \\
& \mathrm{Cu}_{2} \mathrm{O}(\mathrm{s})+\mathrm{O}(\mathrm{g}) \rightarrow 2 \mathrm{CuO}(\mathrm{s}) \\
& \mathrm{Cu}_{2} \mathrm{O}(\mathrm{s})+\mathrm{O}_{3}(\mathrm{~g}) \rightarrow 2 \mathrm{CuO}(\mathrm{s})+\mathrm{O}_{2}(\mathrm{~g}) \\
& \mathrm{Cu}_{2} \mathrm{O}(\mathrm{s})+\mathrm{N}_{2} \mathrm{O}(\mathrm{g})-2 \mathrm{CuO}(\mathrm{s})+\mathrm{N}_{2}(\mathrm{~g}) \\
& 4 \mathrm{Cu}_{2} \mathrm{O}(\mathrm{s})+2 \mathrm{NO}_{2}(\mathrm{~g})-8 \mathrm{CuO}(\mathrm{s})+\mathrm{N}_{2}(\mathrm{~g})(6) \\
& \left.2 \mathrm{Cu}_{2} \mathrm{O}(\mathrm{s})+2 \mathrm{NO}(\mathrm{g}) \rightarrow 4 \mathrm{CuO}(\mathrm{s})+\mathrm{N}_{2}(\mathrm{~g}) \text { ( }\right) \\
& \text { In the equilibria (1) through }
\end{aligned}
$$

(3), variation of Gibbs free energy $(\Delta \mathrm{G})$ obeys the following formula by assuming that the activity of solids is equal to unity:

$\Delta \mathrm{G}=\Delta \mathrm{G}^{\mathrm{O}}-\mathrm{RT} \ln \mathrm{P}_{\mathrm{Ox}}$

In the system including two gas components (reactions (4)-(7)), the relationship between the gas pressure and temperature cannot be uniquely determined because the number of degree of freedom is 2 by the phase rule. The variation of Gibbs free energy $(\Delta G)$ for reaction (4) obeys the following formula. Here, the activity of solids is again unity: $\Delta \mathrm{G}=\Delta \mathrm{G}^{\mathrm{O}}+\mathrm{RT} 1 \mathrm{n}\left(\mathrm{PO}_{2} / \mathrm{PO}_{3}\right)$

In the equilibrium, $\Delta \mathrm{G}$ is zero. Further, we can assume the total pressure to be below $10^{-8}$ bar in the MBE conditions. Therefore, when $\mathrm{Cu}_{2} \mathrm{O}$ and $\mathrm{CuO}$ coexist, $\operatorname{logPO}_{3}$ is approximated by the next formula: $\log P_{3}=\log \left(\exp \left(\Delta G^{\circ} / R T\right)\right)$

$$
+\left(1 / \log _{e} 10\right) \cdot \ln 10^{-8}
$$

From the Gibbs free energy of formation listed in the JANAF Thermodynamic Table, variations of Gibbs free energy $\left(\Delta \mathrm{G}^{\circ}(\mathrm{T}, 1\right.$ bar $\left.)\right)$ of the reactions (1)-(7) were calculated at $300 \mathrm{~K}, 400 \mathrm{~K}, 500 \mathrm{~K}, 700 \mathrm{~K}$, and $1000 \mathrm{~K}$.

Figure 3 shows the relationship between the oxidant gas pressure and temperature for coexistence conditions of $\mathrm{Cu}_{2} \mathrm{O}$ and $\mathrm{CuO}$. An almost linear relationship was obtained between the logarithm of oxidant gas pressure and reciprocal of temperature. CuO is stable above the line. Ozone and atomic oxygen have oxidation abilities stronger than $\mathrm{O}_{2}$. Also $\mathrm{N}_{2} \mathrm{O}$ and $\mathrm{NO}_{2}$, which are not explosive and can be easily obtained with high purity, proved to have an oxidation ability even in UHV condition.

\section{ATOMIC LAYER EPITAXY OF ALKALINE EARTH CUPRATES FILMS BY LASER MBE}

All the known high TC $(\geq 40 \mathrm{~K})$ superconductors have layered perovskite structure containing $\mathrm{CuO}_{2}$ slab. Therefore, we can expect not only to reproduce the structure but also to construct artificially modified new structures, which can exhibit still higher TC superconductivity, by establishing the processing technology of ceramic layer epitaxy, defined as the epitaxial layer-by-layer growth of ceramic thin films. 8 For this purpose it is essential to diagnose the crystal structure and optimize the oxygen content in the growing film by monitoring the surface with reflection high energy electron diffraction (RHEED), as it is proven

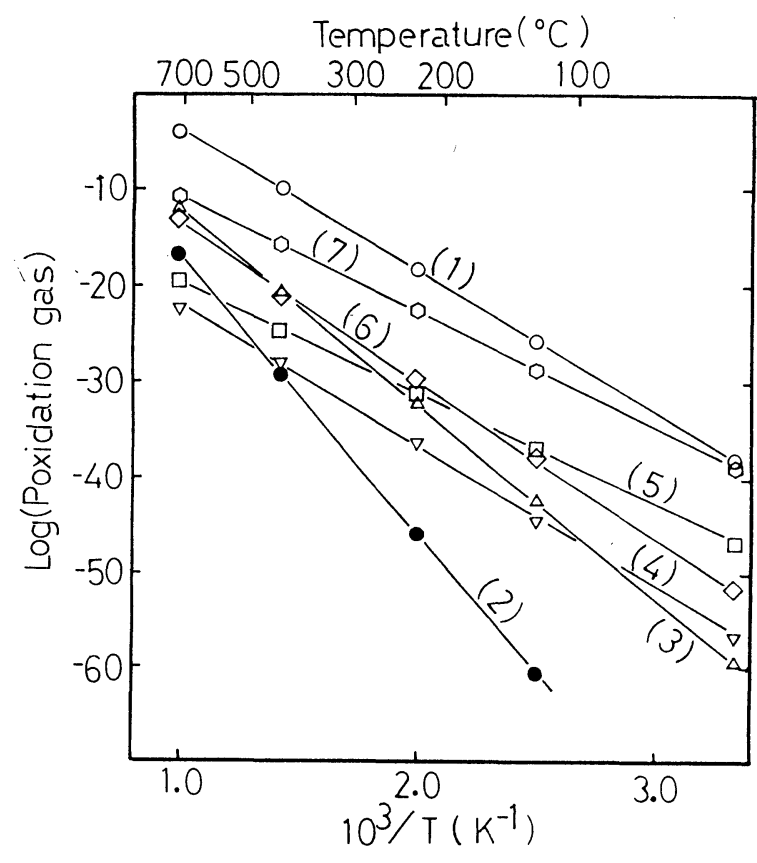

Fig.3. Calculated coexistence lines of $\mathrm{Cu}_{2} \mathrm{O}$ and $\mathrm{CuO}$ for the reactions (1) through (7) in the text. Pox. gas in bar. 
in the fabrication of semiconductor superlattices.

Since RHEED is usually operated in UHV, we must overcome the problem of oxidation in UHV to apply in situ RHEED for the growth of oxide films. From the studies described above, it was considered possible to deposit oxide films with appropriate oxygen contents even in UHV conditions.

\section{4-1. EXPERIMENTAL}

Figure 4 illustrates the laser MBE system we used for the ceramic layer epitaxy. The system is equipped with in situ RHEED and XPS. A focused pulsed ArF excimer laser

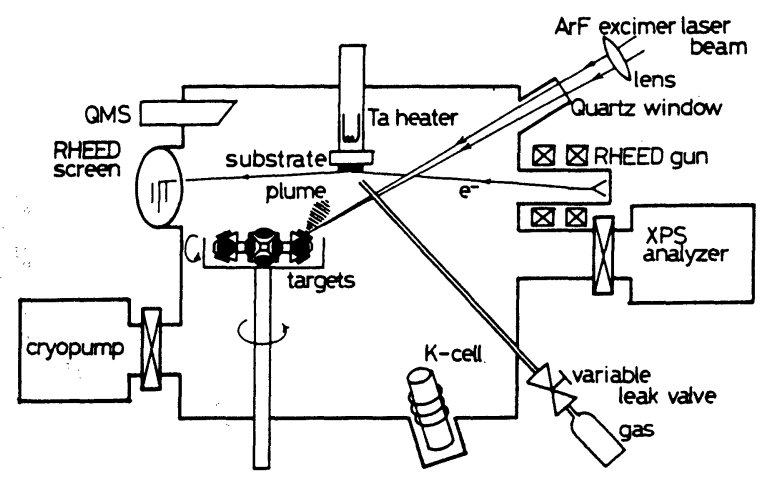

Fig.4. Schematic diagram of laser MBE apparatus with in situ RHEED and in situ XPS analyzers. beam (duration of 20ns, frequency of 2 - $10 \mathrm{~Hz}$, and pulse energy of 80 $\mathrm{mJ} / \mathrm{shot}$ ) was impinged with an energy density of $1 \mathrm{~J} / \mathrm{cm}^{2}$ through a quartz window onto a sintered $(\mathrm{AE}) \mathrm{CuO}_{2}$ ( $\mathrm{AE}=\mathrm{Ca}, \mathrm{Sr}$, or their mixtures) target to deposit a film on $\mathrm{SrTiO}_{3}$ (001) substrates heated at $550{ }^{\circ} \mathrm{C}-700{ }^{\circ} \mathrm{C}$. $\mathrm{NO}_{2}$ was flushed onto the substrate at a pressure between $1 \times 10^{-7}$ and $1 \times$ $10^{-5}$ Torr.

Film thickness was measured by the stylus method. Typical deposition rate was $0.3 \mathrm{~nm} / \mathrm{min}$ in case of $2 \mathrm{~Hz}$ pulsed laser repetition. The structure of films was characterized by X-ray diffractometer (XRD) with monochromated $\mathrm{Cu} \mathrm{K} \alpha$ radiation. The electrical resistivity was measured by the standard four probe method in the temperature range between $7 \mathrm{~K}$ and 300 $\mathrm{K}$.

\section{4-2. RESULTS AND DISCUSSION}

(1) Structure of $\left(\mathrm{Sr}_{1-x} \mathrm{Ca}_{\mathrm{x}}\right) \mathrm{CuO}_{2-\mathrm{y}}$ $(0 \leq \mathrm{x} \leq 1)$ films

Conditions and results of $\left(\mathrm{Sr}_{1-\mathrm{x}} \mathrm{Ca}_{\mathrm{x}}\right) \mathrm{CuO}_{2-\mathrm{y}}$ film growth are summarized in Table 2. From the XRD analysis of deposited films, $\mathrm{SrCuO}_{2-\mathrm{y}}$

Table 2. Results on the preparation of $\left(\mathrm{Sr}_{1-\mathrm{x}} \mathrm{Ca}_{\mathbf{x}}\right) \mathrm{CuO}_{2-\mathrm{y}}$ films $(x=0,0.5,0.86$ and 1$)$ by laser MBE.

\begin{tabular}{|c|c|c|c|c|c|c|}
\hline $\begin{array}{c}\text { Target } \\
\text { composition } \\
(\mathrm{Sr}: \mathrm{Ca}): \mathrm{Cu}\end{array}$ & $\begin{array}{c}\mathrm{NO}_{2} \\
\text { pressure } \\
\left(\times 10^{-7} \text { Torr }\right) \\
\end{array}$ & $\begin{array}{c}\text { Substrate } \\
\text { temp. } \\
\left({ }^{\circ} \mathrm{C}\right)\end{array}$ & $\begin{array}{c}\text { XPS } \\
I_{s} / I_{m}(a \\
C u 2 p l / 2 \\
\end{array}$ & $\begin{array}{l}\text { RHEED }{ }^{\text {b }} \\
\text { pattern }\end{array}$ & $\begin{array}{c}\text { XRD; } \\
\text { c-axis } \\
\text { length } \\
\text { (nm) }\end{array}$ & $\begin{array}{l}(\mathrm{Sr}, \mathrm{Ca}) \mathrm{CuO}_{2} \\
\text { rocking curve } \\
\text { FWHM of }(002) \\
\text { (deg.) }\end{array}$ \\
\hline \multirow{4}{*}{$1: 0: 1$} & \multirow{3}{*}{1} & 750 & 0.14 & spot & c) & c) \\
\hline & & \multirow{2}{*}{700} & 0.38 & \multirow{2}{*}{ streak } & 0.347 & 0.47 \\
\hline & & & not measured & & 0.345 & 0.32 \\
\hline & 5 & 775 & 0.54 & ring & d) & d) \\
\hline \multirow{3}{*}{$0.5: 0.5: 1$} & 0.1 & & 0.19 & spot & un & own peaks \\
\hline & \multirow{2}{*}{1} & \multirow{2}{*}{700} & 0.24 & \multirow{2}{*}{ streak } & 0.332 & 0.43 \\
\hline & & & 0.32 & & 0.332 & 0.39 \\
\hline $0.14: 0.86: 1$ & 1 & 700 & 0.40 & spot & 0.325 & 0.85 \\
\hline $0: 1: 1$ & 1 & 700 & not measured & spot & $(101) /$ & b. oriented ${ }^{e)}$ \\
\hline
\end{tabular}

a) XPS peak area ratio of the satellite to the main for $\mathrm{Cu} 2 \mathrm{p} 1 / 2$.

b) Streaky RHEED patterns indicated the film orientation of $\left(\mathrm{Sr}_{\mathrm{x}} \mathrm{Ca}_{1-\mathrm{x}}\right) \mathrm{CuO}_{\mathrm{y}}-$

$(001) / / \mathrm{SrTiO}_{3}(001)$ and $\left(\mathrm{Sr}_{\mathrm{x}} \mathrm{Ca}_{1-\mathrm{x}}\right) \mathrm{CuO}_{\mathrm{y}}[010] / / \mathrm{SrTiO}_{3}[010]$.

c) Mixed phases of $\mathrm{Sr}_{2} \mathrm{Cu}^{\mathrm{II}} \mathrm{O}_{3}$ and $\mathrm{SrCu}_{2}{ }_{2} \mathrm{O}_{2}$.

d) Mixed phases of $\mathrm{Sr}_{2} \mathrm{CuO}_{3}$ and orthorhombic-SrCuO

e) Only one peak observed at $d=0.243 \mathrm{~nm}$ is assigned to $\mathrm{CaCuO}_{2} 101$ (d=0.244nm). 
and $\left(\mathrm{Sr}_{0} . \mathrm{Ca}_{0.5}\right) \mathrm{CuO}_{2-\mathrm{y}}$ films were confirmed to be grown epitaxially in the tetragonal phase, when $(1-5) \mathrm{x}$ $10^{-7}$ Torr $\mathrm{NO}_{2}$ was present in the chamber. The oxidation states of copper in the as-grown $\left(\mathrm{Sr}_{1-\mathrm{x}} \mathrm{Ca}_{\mathrm{x}}\right) \mathrm{CuO}_{2-\mathrm{y}}(\mathrm{x}=0,0.5,0.86)$ films were essentially the same $\left(\mathrm{Cu}^{2+}\right)$ as in CuO judging from their XPS satellite structures in $\mathrm{Cu} 2 \mathrm{p}$ core level spectra as well as from the kinetic energy of $\mathrm{Cu} \quad \mathrm{L}_{3} \mathrm{M}_{4} 5_{4} \mathrm{M}_{4}$ Auger peak. 9 Therefore, y should be close to zero.

Figure 5 shows the phase diagram for $\mathrm{Sr}-\mathrm{Cu}-\mathrm{O}$ system as functions of $\mathrm{NO}_{2}$ pressure and substrate temperature. The optimum conditions for the growth of tetragonal $\mathrm{SrCuO}_{2-\mathrm{y}}$ films were at about $700{ }^{\circ} \mathrm{C}$ and $\mathrm{NO}_{2}$ pressure of $1 \times 10^{-7}$ Torr. In the absence of $\mathrm{NO}_{2}$, films were in mixed phases and contained $\mathrm{Cu}$ in both monoand di-valent states, as verified by $\mathrm{XRD}$ and XPS, respectively.

(2) Growth mode of $\left(\mathrm{Sr}_{1-x} \mathrm{CO}_{x}\right) \mathrm{CuO}_{2-y}$ films

RHEED patterns for the $\left(\mathrm{Sr}_{0.5} \mathrm{Ca}_{0.5}\right)_{\mathrm{CuO}_{2}-\mathrm{y}}$ and $\mathrm{SrCuO}_{2-\mathrm{y}}$ film growth at $700{ }^{\circ} \mathrm{C}$ and $1 \times 10^{-7^{2-y}}$ Torr $\mathrm{NO}_{2}$ varied with the deposition time.

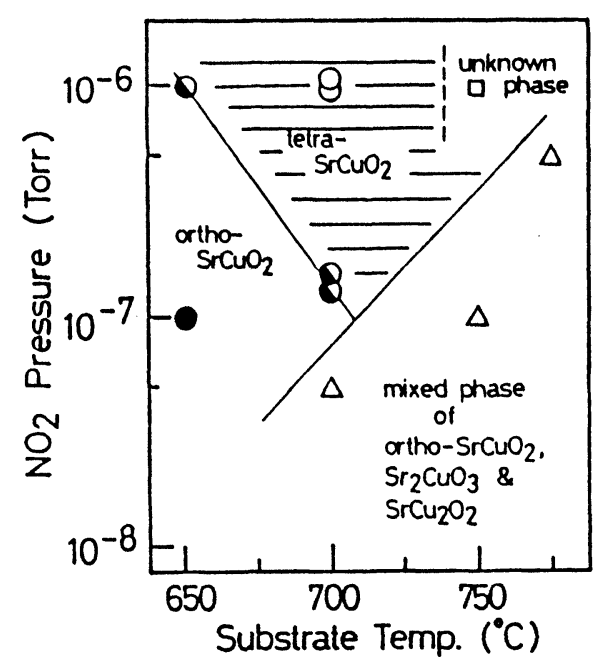

Fig.5. Phase diagram of $\mathrm{Sr}-\mathrm{Cu}-\mathrm{O}$ system prepared by laser MBE under the various substrate temperatures and $\mathrm{NO}_{2}$ gas pressures.
As soon as the film deposition started, the RHEED pattern changed from the substrate streaks into broad spots. After 1 to $2 \mathrm{~nm}$ thick film growth, the RHEED pattern returned to be streaks. Figure 6 (b) shows the intensity oscillation observed at the RHEED central streak during the $\mathrm{SrCuO}_{2-y}$ film deposition. The oscillation period of $0.33 \mathrm{~nm}$ is the same as the (001) interplane distance of tetragonal $\mathrm{SrCuO}_{2}$, indicating that the film was grown by a layer-bylayer mode, i. e. by stacking twodimensional $\mathrm{SrCuO}_{2-\mathrm{y}}$ unit cells. 10 Figure 6 also shows a significant effect of $\mathrm{NO}_{2}$ gas pressure on the layer-by-layer growth. The RHEED intensity oscillation was observed clearly under the condition optimum for the epitaxial growth of tetragonal $\mathrm{SrCuO}_{2-\mathrm{y}}$.

\section{(3) Electric property}

$$
\text { As-grown } \mathrm{SrCuO}_{2-\mathrm{y}} \text { and }
$$

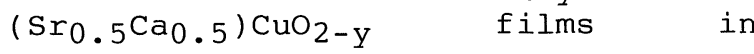
tetragonal phase had black color and very low resistivities in the order of $10^{-3} \mathrm{~s}^{-1} \mathrm{~cm}$. On the other hand,

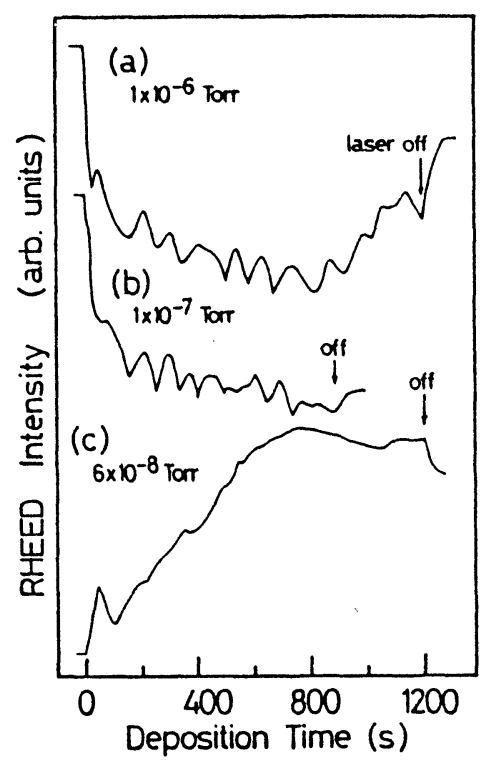

Fig.6. RHEED intensity oscillations during the deposition of $\mathrm{SrCuO}_{2-y}$ films at $700^{\circ} \mathrm{C}$ under various $\mathrm{NO}_{2}$ pressures. 


\begin{abstract}
mixed phase films prepared in the absence of $\mathrm{NO}_{2}$ were insulative. The tetragonal phase films had resistivities decreasing linearly with the temperature decrease from $300 \mathrm{~K}$ to $7 \mathrm{~K}$. Such a metallic behavior of $\mathrm{SrCuO}_{2-\mathrm{y}} \mathrm{film}$ was observed for the first time and attracts our interest in the development of superconductivity by a slight modification of composition, lattice structure, and/or oxygen nonstoichiometory.
\end{abstract}

\section{ACKNOWLEDGEMENTS}

The author expresses his sincere thanks to Drs. M. Yoshimoto and $T$. Hashimoto and Messers $H$. Nagata, $T$. Tsukahara, and S. Gonda for their collaboration. This work was supported in part by the grant-in-aid for Scientific Research on Chemistry of New High Tc Superconductors from Ministry of Education, Science and Culture of Japan.

\section{REFERENCES}

${ }^{1}$ K. Moriwaki, Y. Enomoto, S. Kubo, T. Murakami, Jpn. J. Appl. Phys., 27, L2075(1988)

2 D. D. Berkeley et al., Appl. Phys. Lett., 53, 1973(1988)

3 M. Kanai, T. Kawai, S. Kawai,

H. Tabata, Appl. Phys. Lett., 54, 1802(1989)

$4 \mathrm{~S}$. Watanabe, M. Kawai, T. Hanada, Jpn. J. Appl. Phys., 29, L1111 (1990)

5 K. Takeuchi, M. Kawasaki,

M. Yoshimoto, Y. Saito,

H. Koinuma, Jpn. J. Appl. Phys., 29, L70(1990)

6 S. Nagata, M. Kawasaki,

H. Koinuma, Jpn. J. Appl. Phys., 27, L870(1988)

7 T. Hashimoto, H. Koinuma, K. Kishio, Jpn. J. Appl. Phys., 30, 1685(1991)

8 H. Koinuma, H. Nagata, T. Tsukahara, S. Gonda,

M. Yoshimoto, Appl. Phys. Lett., 58, $2027(1991)$

9 A. Fujimori, E. T. Muromachi, Y. Uchida, B. Okai, Phys. Rev. B, $35,8814(1987)$

10 T. Tsukahara, M. Yoshimoto, H. Nagata, T. Hashimoto, S. Gonda, H. Koinuma, Solid state Ionics, in press 


\title{
The 2nd Tokai University International Workshop \\ on \\ SUPERCONDUCTIVITY \\ (TUIWS)
}

\author{
October 9-12, 1991
}

Tokai University Pacific Center

2241 Kapiolani Blvd. Honolulu, Hawaii

(Phone: 808-973-4100 Fax: 808-973-4107)

\section{CONFERENCE ORGANIZERS}

\section{Organizing Committee (Tokai University) \\ Chair; Tatsuro MATSUMAE \\ (President of Tokai University) \\ Sonosuke KATORI \\ Shoji YOSHIDA \\ Kimikazu MATSUYAMA \\ Norio MATSUMAE \\ Yoshio MIHARA \\ Hajime YANO \\ Takashi MATSUMOTO \\ Toru HIRAYAMA \\ Mamoru KAWAKAMI}

\section{Conference Organizers}

$\begin{array}{ll}\text { Chair; } & \text { Sadao NAKAJIMA } \\ \text { Co-Chair; } & \text { Shoji TANAKA } \\ \text { Co-Chair; } & \text { Kyoji TACHIKAWA } \\ & \text { Mamoru KAWAKAMI } \\ & \text { Hideomi KOINUMA }\end{array}$

\section{Program Committee}

Chair; Tadashi SHIRAISHI

Hideomi KOINUMA

Kazumasa TOGANO

Naoto NAGAOSA

Yoshitake NISHI

Yuh SHIOHARA

Secretariat

Chair; Tadashi SHIRAISHI

Ichiro NAKADA

Shusuke YOMO

Yasunari KURIHARA

Tetsunobu TAKAYAMA

Minoru HAYAMA

Masaaki IGARASHI 